\title{
PERSEPSI MASYARAKAT MADURA TERHADAP PERAN TUMBUHAN ETNOFARMAKA DI KABUPATEN SUMENEP
}

\author{
Dody Tri Kurniawan ${ }^{1 *}$, Ika Fatmawati ${ }^{2)}$ \\ Dosen Fakultas Pertanian Universitas Wiraraja \\ email : dodytri@wiraraja.ac.id dan $\underline{\text { kka agribisnis@yahoo.co.id }}$
}

\begin{abstract}
ABSTRAK
Salah satu wilayah di Pulau Madura yang memiliki kontribusi besar dalam produksi tanaman obat adalah Kabupaten Sumenep. Sumenep juga dikenal sebagai pusat pembuatan ramuan obat tradisional. Peran pentingnya etnofarmaka sebagai sediaan bahan baku obat tradisional di lingkungan masyarakat Sumenep perlu ditanamkan dari generasi ke genarasi berikutnya. Adanya interaksi tersebut membentuk persepsi sebagai rangsangan dalam sikap dan tindakan manusia terhadap tanaman obat. Maka penting bagi peneliti untuk menelaah lebih lanjut mengenai persepsi masyarakat Madura terhadap peran tanaman etnofarmaka di Kabupaten Sumenep. Tujuan penelitian ini adalah: 1) Mendeskripsikan peran etnofarmaka sebagai bahan baku sediaan obat tradisional pada masyarakat Madura; 2)Mengetahui persepsi masyarakat mendasarkan gol umur terhadap peran etnofarmaka; 3)Mengetahui prioritas peran tumbuhan etnofarmaka di kalangan masyarakat Madura. Penelitian dilakukan di Kecamatan Rubaru, Ambunten, Lenteng, Manding dan Batuan. Penentuan lokasi tersebut ditentukan secara sengaja (purposive) dengan pertimbangan bahwa kelima Kecamatan tersebut merupakan sentra produksi beberapa macam tanaman biofarmaka di Kabupaten Sumenep. Metode analisa yang digunakan adalah analisis deskriptif untuk menggambarkan presepsi masyarakat Madura mengenai etnofarmaka dengan menggunakan Skala Likert serta digunakan observasi berpartisipasi dalam menelaah lebih lanjut peran etnofarmaka dalam presepsi masyarakat. Adapun Hasil dari penelitian ini adalah jenis penggunaan tanaman Etnofarmaka untuk penyakit di Kabupaten Sumenep seperti Jahe untuk pengobatan batuk, masuk angin, obat bisul; Kencur untuk pengobatan batuk, selesai melahirkan; Kunyit untuk pengobatan panas dalam, tipus, panu, tidak nafsu makan; Temu Ireng untuk pengobatan tidak nafsu makan, batuk, cacingan; Temulawak untuk pengobatan kolesterol, demam; Lengkuas untuk pengobatan rematik, ganguan pencernaan; Temu Kunci untuk pengobatan gangguan lambung; Mengkudu untuk lemah jantung, keputihan; dan Lidah Buaya untuk pengobatan batuk, rambut rontok, luka; penggunaan Etnofarmaka secara urut pada usia terbesar dengan 38\% terdapat pada umur 41-50 tahun, kemudian $24 \%$ pada kisaran umur 20-30 tahun, dan 22\% pada umur antara 31-40 tahun, sedangkan 16\% pada umur 51-60 tahun dan dibawah 20 tahun sangat sedikit; dan Prioritas peran tumbuhan Etnofarmaka di kalangan masyarakat Madura sebagai tumbuhan pengobatan dengan tingkat kemudahan mendapatkan, dapat digunakan di semua golongan usia, tingkat kesesuaian kebutuhan oleh masyarakat dan penggunaan tanpa efek samping.
\end{abstract}

Kata Kunci: Persepsi, Masyarakat, Madura, dan Etnofarmaka 


\section{PENDAHULUAN}

Kelompok etnis yang mempunyai hubungan erat antara masyarakat dengan tumbuhan obat biasa disebut dengan etnofarmaka. Menurut Zuhud dalam Zaman, Dkk. (2013) diantara 400 kelompok etnofarmaka ternyata Masyarakat Madura termasuk dalam etnis ini. Masyarakat Madura banyak memproduksi serta menggunakan tumbuhan obat sebagai obat tradisional dalam kehidupan sehariharinya yang biasa mereka sebet dengan jamu. Salah satu wilayah di Pulau Madura yang memiliki kontribusi besar dalam produksi tanaman obat adalah Kabupaten Sumenep. Sumenep juga dikenal sebagai pusat pembuatan ramuan obat tradisional. Kabupaten Sumenep memiliki luas lahan pertanian seluas $168.558 \mathrm{Ha}$ yang tersebar didaratan dan kepulauan (BPS Sumenep, 2017).

Sentra produksi tanaman obat/biofarmaka di Kabupaten Sumenep yaitu terletak pada Kecamatan Rubaru dan Ambunten. Produksi tanaman biofarmaka di Kecamatan Rubaru yaitu Temulawak (14.236 kg), Temu Ireng $(17.573 \mathrm{~kg})$ serta Lengkuas (178.937 kg), sedangkan pada Kecamatan Ambunten yaitu Jahe (10.700 kg), Mengkudu (8.091 kg) dan Kencur (8.983 kg) (Dinas Pertanian dan Perkebunan Kabupaten Sumenep, 2017).

Sumenep merupakan salah satu daerah industri jamu, adapun pasokan bahan baku tanaman obat didapatkan melalui sediaan produksi regional, sedangkan beberapa tanaman obat yang tidak dibudidayakan di Sumenep dipasok dari luar daerah. Akan tetapi generasi muda saat ini khususnya di Kabupaten Sumenep kurang mengetahui peran tumbuhan sebagai bahan baku pembuatan jamu tradisional. Hal ini akan berdampak terhadap peran tanaman biofarmaka dalam kelestarian industri obat tradisional.
Peran pentingnya etnofarmaka sebagai sediaan bahan baku obat tradisional di lingkungan masyarakat Sumenep perlu ditanamkan dari generasi ke genarasi berikutnya. Adanya interaksi tersebut membentuk persepsi sebagai rangsangan dalam sikap dan tindakan manusia terhadap tanaman obat. Maka penting bagi peneliti untuk menelaah lebih lanjut mengenai persepsi masyarakat Madura terhadap peran tanaman etnofarmaka di Kabupaten Sumenep.

\section{KAJIAN TEORITIS \\ Etnofarmaka}

Etnofarmaka berasal dari dua suku kata, yaitu etno (etnis) dan farmaka. Kata etno berarti masyarakat adat/kelompok sosial dalam sistem sosial atau kebudayaan yang mempunyai arti atau kedudukan tertentu karena keturunan, adat istiadat, agama, bahasa, dan lain sebagainya. Sedangkan farmaka adalah tumbuhan obat. Pengertian etnofarmaka secara lebih jelas dipaparkan oleh Purwanto (1999) yaitu suatu interaksi antara masyarakat setempat dengan lingkungan hidupnya, yang lebih mengutamakan pemanfaatan tanaman obat sebagai bahan obat, makanan, perlindungan, maupun berbagai acara adat yang masih lekat dengan alam.

Sediaan etnofarmasetika obat minum umumnya disiapkan dalam bentuk godogan yang hingga sekarang masih eksis dan dikenal dengan sebutan jamu gendong. Sedangkan sediaan etnofarmasetika obat luar yang berupa param kocok biasanya dibuat dengan cara menumbuk bahan dengan sejumlah air, kemudian dimasukkan ke dalam botol dan digunakan dengan cara dibalurkan. Bedak dsiapkan dengan cara menumbuk halus bahan-bahan kering dan dicampur homogen, bila perlu disaring dengan kain. 


\section{Tanaman Obat}

Keanekaragaman tanaman yang dimiliki Indonesia perlu diperhatikan. Terutama tanaman yang memiliki manfaat besar bagi kesehatan masyarakat. Tanaman ini biasa disebut dengan tanaman obat yang digunakan sebagai bahan baku obat herbal. Tanaman obat

Sedangkan Nasrudin (2005) memberikan pengertian tumbuhan obat sebagai tumbuhan yang dipercaya oleh masyarakat leluhur sebagai obat tradisional yang pada saat ini dibuktikan secara medis dan telah diteliti sehingga diketahui bahwa terdapat kandungan yang bermanfaat sebagai obat kesehatan manusia. Masyarakat meracik berbagai tanaman obat yang dijadikan sebagai ramuan yang kemudian disebut sebagai obat herbal.

Bahan baku obat tradisional ternyata lebih banyak menggunakan tanaman obat dibandingkan mineral maupun hewani, tanaman obat mendominasi kandungan dalam obat herbal. Ramuan yang dijadikan sebagai obat herbal atau obat tradisional digunakan oleh masyarakat secara turuntemurun (Prananingrum, 2007).

Obat tradisional merupakan obat-obatan atau media penyembuh yang mulai dari jaman dahulu di percaya dan diyakini baik secara turun-temurun dari nenek moyang maupun dari segi kepercayaan adat-isitidat yang bersifat magic (spontan, kebetulan) maupun pengetahuan tradisional. Obat tradisional sangat mudah di dapat dan diperoleh karena keberadaanya sangat erat dengan lingkungan dan alam, selain itu pada obat tradisional terdapat banyak manfaat yang baik bagi tubuh selain sebagai obat-obatan. Dan juga pada beberapa bagian obat-obatan tradisional mulai dari bagian, akar (radix), rimpang (rhizome), batang (caulis), buah (fructus), daun (folia) dan bunga (flos) dapat digunakan sebagai media obat (Nasrudin, 2005).

\section{Persepsi Masyarakat Terhadap Peran Etnofarmaka}

Istilah persepsi sering disebut juga dengan pandangan, gambaran, atau anggapan. Perolehan panca indera yang dianalisis oleh kmampuan manusia yang kemudian didapatkan interpretasi akan suatu hal tertentu melalui pendapat, sikap dan perilaku juga bisa disebut sebagai presepsi.

Menurut Haidar dan Fajar (2016) masyarakat Jawa termasuk Madura sudah terbiasa hidup dengan berbagai persepsi tradisional yang mempengaruhi cara bersikap dan menentukan keputusan dalam kehidupannya, persepsi ini akan membentuk kebudayaan khas yang membedakan kepribadian masyarakat Madura dengan masyarakat lain. Salah satu persepsi yang masih banyak dipercayai masyarakat Madura adalah pandangan terhadap beberapa macam tumbuhan yang diyakini memiliki kemampuan-kemampuan untuk membantu mengatasi permasalahan dalam kehidupan .

Masyarakat Madura sangat mempercayai bahwa tanaman obat mempunyai khasiat yang penting terhadap kesehatan masyarakat. Sebab dalam mengatasi penyakit atau gangguan kesehatan yang mereka alami, masyarakat Madura akan mencari obat alami yang berbahan baku tanaman obat sehingga terbentuklah sebuah ramuan yang biasa disebut dengan jamu.

\section{METODOLOGI PENELITIAN Lokasi Penelitian}

Penelitian dilakukan di

Kecamatan Rubaru, Ambunten, Lenteng, Manding dan Batuan. Penentuan lokasi tersebut ditentukan secara sengaja (purposive) dengan pertimbangan bahwa kelima Kecamatan tersebut merupakan sentra produksi beberapa macam tanaman biofarmaka di Kabupaten Sumenep. 


\section{Metode Pengambilan Sampel}

Penentuan sampel penelitian ini dilakukan secara sengaja (purposive sampling) dengan pertimbangan bahwa responden mempunyai pengaruh cukup penting dan memiliki banyak informasi tentang ethnofarmaka.

\section{Metode Pengumpulan Data}

Metode pengumpulan data yang digunakan dengan cara studi secara langsung pada masyarakat setempat. Data yang dikumpulkan dan diperoleh dalam penelitian ini dibedakan menjadi dua yaitu :

- Data Primer
a) Wawancara (interview)
b) Observasi
c) Survey,

\section{- Data Sekunder}

Dalam penelitian ini data sekunder diperoleh dari literatur, buku, kantor desa, tokoh agama, petani dan beragai literatur dari internet.

\section{Metode Analisis Data}

\section{Analisis Deskriptif}

\section{Skala Likert}

Skala Likert merupakan alat yang digunakan untuk mengukur sikap, pendapat, dan persepsi seseorang atau kelompok orang tentang sebuah fenomena sosial, sehingga dapat menjawab permasalahan pada bagian pertama yaitu tentang persepsi masyarakat terhadap peran tumbuhan etnofarmaka. Dengan skala likert, maka variabel yang akan diukur dijabarkan menjadi indikator variabel. Kemudian indikator tersebut dijadikan sebagai tolak ukur untuk menyusun item-item instrumen yang dapat berupa pertanyaan atau pernyataan.

Djaali (2008) mngemukakan pengertian skala likert sebagai skala yang digunakan dalam mengukur sikap, pendapat, dan persepsi seseorang atau kelompok mengenai suatu fenomena.
Skala digunakan untuk memudahkan dalam pengukuran jenjang tertentu. Skala ini berinteraksi 1-5 dengan pilihan jawaban sebagai berikut :

1. Sangat tidak setuju (sts) dengan nilai skor 1

2. Tidak setuju (ts) dengan nilai skor 2

3. Netral (n) dengan nilai skor 3

4. Setuju (s) dengan nilai skor 4

5. Sangat setuju (ss) dengan nilai skor 5

$$
\mathbf{B B}=\mathbf{N s i} \times \mathbf{S J j}
$$

Keterangan :

$\mathrm{BB}=$ Bobot nilai

Nsi $=$ Nilai soal ke $1,2, \ldots \ldots \ldots . .5$

$\mathrm{SJj}=$ Skor jawaban ke $1,2, \ldots \ldots . . .5$

Rumus untuk mencari indeks nilai (IN) yaitu menggunakan persamaan sebagai berikut :

Keterangan :

$$
I N=\frac{\Sigma(N S i \times S J i)}{\Sigma(N S i \times S J \max )}
$$

IN = Indeks nilai

Nsi $=$ Nilai soal ke $1,2, \ldots .5$

$\mathrm{SJi}=$ Skor jawaban ke $1,2, \ldots 5$

Sjmax $=$ Skor jawaban $\max 4$

\section{Observasi Berpartisipasi}

Sekaran dan Bougie (2013) mendefinisikan observasi berpartisipasi sebagai observasi yang diikutsertai peran peneliti dalam kegiatan objek yang sedang diamati atau yang digunakan sebagai sumber data penelitian. Disini, peneliti memasuki organisasi atau lingkungan penelitian, dan menjadi bagian tim kerja. Dengan observasi partisipan ini, maka data yang diperoleh akan lebih lengkap, tajam, dan sampai mengetahui tingkat makna dari setiap perilaku yang nampak.

\section{PEMBAHASAN}

\section{Deskripsi Peran Tanaman Etnofarmaka di Madura}

Tumbuhan etnofarmaka di Kabupaten Sumenep memiliki luasan dan produksi sebagai berikut : Jahe 
(59957 $\mathrm{M}^{2}$ dan $78585 \mathrm{Kg}$ ), Kencur (43542 $\mathrm{M}^{2}$ dan $60857 \mathrm{Kg}$ ), Kunyit (38182 M ${ }^{2}$ dan $110402 \mathrm{Kg}$ ), Temu Ireng $\left(35983 \mathrm{M}^{2}\right.$ dan $\left.66085 \mathrm{Kg}\right)$, Temulawak $\left(25283 \mathrm{M}^{2}\right.$ dan $\left.54797 \mathrm{Kg}\right)$, Lengkuas $\left(65369 \mathrm{M}^{2}\right.$ dan $367810 \mathrm{Kg}$ ), Temu Kunci (14126 $\mathrm{M}^{2}$ dan $\left.17229 \mathrm{Kg}\right)$, Mengkudu (3475 $\mathrm{M}^{2}$ dan $112662 \mathrm{Kg}$ ) dan Lidah Buaya (30 $\mathrm{M}^{2}$ dan $224 \mathrm{Kg}$ ).

Pada umumnya pengunaan tanaman Etnofarmaka untuk kebutuhan pengobatan dilingkup keluarga, namun banyak tanaman tersebut juga dijadikan campuran obat-obatan herbal oleh home industri di Kabupaten Sumenep, misalnya : Lengkuas dan Jahe sebagai penambah stamina khususnya untuk lelaki, Mengkudu untuk mengatasi keputihan, Kunyit sebagai obat mengurangi nyeri saat haid, dll.

Tumbuhan Etnofarmaka menurut hasil survey kenbanyakan didapatkan dari hasil menanam sendiri yaitu sebesar $63 \%$ dan $37 \%$ dari membeli. Dilihat dari prosentase tersebut dapat disimpulkan bahwa petani sudah memanfaatkan hasil tanaman Etnofarmaka untuk kebutuhan pengobatan. Adapun pengetahuan tentang manfaat dan meracik tanaman tersebut banyak diperoleh dari turuntemurun keluarga sendiri.

\section{Persepsi Masyarakat Berdasarkan Gol Umur Terhadap Peran Etnofarmaka}

Tumbuhan Etnofarmaka dapat dijadikan pengobatan herbal untuk segala umur, baik untuk remaja maupun lansia. Adapun pemanfaatannya untuk penyakit yang biasa dialami pada segala umur.

Tabel 1. Persepsi Masyarakat Berdasarkan Gol Umur

\begin{tabular}{|c|c|c|c|}
\hline No & $\begin{array}{c}\text { Umur } \\
\text { (Tahun } \\
\text { ) }\end{array}$ & $\begin{array}{c}\text { Responde } \\
\text { n (orang) }\end{array}$ & $(\boldsymbol{\%})$ \\
\hline 1 & $20-30$ & 12 & $24 \%$ \\
\hline 2 & $31-40$ & 11 & $22 \%$ \\
\hline 3 & $41-50$ & 19 & $38 \%$ \\
\hline
\end{tabular}

\begin{tabular}{|c|c|c|r|}
4 & $51-60$ & 8 & $16 \%$ \\
\hline Jumlah & $\mathbf{5 0}$ & $\mathbf{1 0 0 \%}$ \\
\hline
\end{tabular}

Sumber : Data Primer diolah 2019

Tabel 1. menjelasakan bahwa hampir diseluruh tingkatan umur mereka telah memahami tentang peran Etnofarmaka. Apabila di rating, terbesar dengan 38\% terdapat pada umur 41-50 tahun, kemudian $24 \%$ pada kisaran umur 20-30 tahun, dan $22 \%$ pada umur antara 31-40 tahun, sedangkan $16 \%$ pada umur 51-60 tahun. Hal ini menunjukkan bahwa pemahaman tentang manfaat etnofarmaka telah diperoleh sejak umur 20 tahun dan semakin terasa pentingnya pada umur diantara 41 sampai 50 tahun atau pada umur produktif.

Pada umur produktif ini masyarakat mampu mengolah informasi dan menganalisa potensi sumber daya alam khususnya tumbuhan Etnofarmaka menjadi penting untuk dijadikan alternatif pengobatan terhadap berbagai penyakit yang ada di sekitar mereka. Selain digunakan untuk diri sendiri mereka juga menyajikan hal tersebut kepada orang tua mereka (51-60 tahun) namun sangat jarang atau hampir tidak pernah digunakan pengobatan pada anak-anak mereka dibawah umur 20 tahun.

\section{Prioritas Peran Tumbuhan Etnofarmaka Di Kalangan Masyarakat Madura}

Prioritas ini didasarkan dari adanya persepsi dikalangan masyarakat, dimana persepsi ini akan menunjukkan alasan terkuat masyarakat tentang pentingnya Etnofarmaka terhadap pengobatan herbal di masyarakat. Persepsi masyarakat terhadap peran Etnofarmaka disajikan dalam lia indikator. Adapun kelima indikator tersebut adalah : tingkat kebutuhan masyarakat, tingkat penggunaan, tingkat kemanfaatan, tingkat keberhasilan, tingkat kemudahan bahan didapat. Tingkat kebutuhan masyarakat 
meliputi: kesesuaian kebutuhan masyarakat, kebutuhan penyembuhan penyakit, kegunaan turun-temurun. Tingkat penggunaan meliputi : frekuensi pemakaian, golongan umur penggunaan. Pada tingkat kemanfaatan meliputi: adanya efek samping, manfaat etnofarmaka lebih baik dari obat kimia, dan keyakinan kesembuhan penyakit. Sedangkan tingkat keberhasilan meliputi : penggunaan etnofarmaka oleh masyarakat, dan konsistensi penggunaan. Kemudian untuk indikator tingkat kemudahan bahan didapat meliputi: kemudahan dan ketersediaan.

Tabel 2. Rekapitulasi Persepsi Masyarakat Terhadap Peran Etnofarmaka

\begin{tabular}{|c|c|c|c|c|}
\hline No. & Indikator & Sub Indikator & Skor & Ket. \\
\hline \multirow{3}{*}{1} & \multirow{3}{*}{$\begin{array}{l}\text { Persepsi } \\
\text { Masyarakat } \\
\text { Menurut } \\
\text { Tingkat } \\
\text { Kebutuhan } \\
\text { Masyarakat }\end{array}$} & Kesesuaian Kebutuhan Masyarakat & 202 & Setuju \\
\hline & & Kebutuhan Penyembuhan Penyakit & 189 & Setuju \\
\hline & & Kegunaan Turun-temurun & 175 & Setuju \\
\hline \multirow[b]{2}{*}{2} & \multirow{2}{*}{$\begin{array}{l}\text { Persepsi } \\
\text { Masyarakat } \\
\text { Menurut } \\
\text { Tingkat } \\
\text { Penggunaan } \\
\end{array}$} & Frekuensi Pemakaian Etnofarmaka & 185 & Setuju \\
\hline & & $\begin{array}{l}\text { Etnofarmaka digunakan di semua } \\
\text { golongan usia }\end{array}$ & 208 & Setuju \\
\hline \multirow{3}{*}{3} & \multirow{3}{*}{$\begin{array}{l}\text { Persepsi } \\
\text { Masyarakat } \\
\text { Menurut } \\
\text { Tingkat } \\
\text { Kemanfaatan }\end{array}$} & $\begin{array}{l}\text { Penggunaan Etnofarmaka Memberikan } \\
\text { Efek Samping }\end{array}$ & 97 & $\begin{array}{l}\text { Tidak } \\
\text { Setuju }\end{array}$ \\
\hline & & $\begin{array}{l}\text { Manfaat Etnofarmaka Lebih Baik dari } \\
\text { Obat Kimia }\end{array}$ & 190 & Setuju \\
\hline & & $\begin{array}{l}\text { Semua Penyakit Dapat Disembuhkan } \\
\text { Dengan Etnofarmaka }\end{array}$ & 177 & Setuju \\
\hline \multirow[b]{2}{*}{4} & \multirow{2}{*}{$\begin{array}{l}\text { Persepsi } \\
\text { Masyarakat } \\
\text { Menurut } \\
\text { Tingkat } \\
\text { Keberhasilan } \\
\end{array}$} & $\begin{array}{l}\text { Penggunaan Etnofarmaka Oleh } \\
\text { Masyarakat }\end{array}$ & 178 & Setuju \\
\hline & & Konsistensi Penggunaan Etnofarmaka & 162 & Setuju \\
\hline \multirow[b]{2}{*}{5} & \multirow{2}{*}{$\begin{array}{l}\text { Persepsi } \\
\text { Masyarakat } \\
\text { Menurut } \\
\text { Tingkat } \\
\text { Kemudahan } \\
\text { Didapat }\end{array}$} & Kemudahan Didapat & 209 & Setuju \\
\hline & & Ketersediaan di Pertokoan & 148 & Ragu-ragu \\
\hline
\end{tabular}

Sumber : Data Primer diolah 2019 
Berdasarkan Tabel 2. diatas prioritas peran tumbuhan Etnofarmaka di kalangan masyarakat Madura sebagai tumbuhan pengobatan dengan tingkat kemudahan mendapatkan, dapat digunakan di semua golongan usia, tingkat kesesuaian kebutuhan oleh masyarakat dan penggunaan tanpa efek samping.

\section{KESIMPULAN DAN SARAN}

\section{Kesimpulan}

1. Jenis penggunaan tanaman Etnofarmaka untuk penyakit di Kabupaten Sumenep seperti Jahe untuk pengobatan batuk, masuk angin, obat bisul; Kencur untuk pengobatan batuk, selesai melahirkan; Kunyit untuk pengobatan panas dalam, tipus, panu, tidak nafsu makan; Temu Ireng untuk pengobatan tidak nafsu makan, batuk, cacingan; Temulawak untuk pengobatan kolesterol, demam; Lengkuas untuk pengobatan rematik, ganguan pencernaan; Temu Kunci untuk pengobatan gangguan lambung; Mengkudu untuk lemah jantung, keputihan; dan Lidah Buaya untuk pengobatan batuk, rambut rontok, luka.

2. Penggunaan Etnofarmaka secara urut pada usia terbesar dengan 38\% terdapat pada umur 41-50 tahun, kemudian $24 \%$ pada kisaran umur 20-30 tahun, dan 22\% pada umur antara 31-40 tahun, sedangkan 16\% pada umur 51-60 tahun dan dibawah 20 tahun sangat sedikit.

3. Prioritas peran tumbuhan Etnofarmaka di kalangan masyarakat Madura sebagai tumbuhan pengobatan dengan tingkat kemudahan mendapatkan, dapat digunakan di semua golongan usia, tingkat kesesuaian kebutuhan oleh masyarakat dan penggunaan tanpa efek samping.

\section{Saran}

1. Perlu dilakukannya penataan yang terencana tentang agroindustri Tumbuhan Etnofarmaka oleh Pemerintah agar menambah gairah petanai untuk membudidayakan dengan lebih baik lagi.

2. Perlu dilakukan edukasi tentang penerapan teknologi tepat guna pada pasca panen sehingga ketersediaan tumbuhan Etnofarmaka lebih terjamin di pertokoan.

\section{DAFTAR PUSTAKA}

BPS. 2017. Kabupaten Sumenep Dalam angka Tahun 2017. BPS Kabupaten Sumenep

Djaali. 2008. Skala Likert. Jakarta: Pustaka Utama.

Dinas Pertanian dan Perkebunan Sumenep. 2017. Panen dan Produksi Tanaman Biofarmaka Kabupaten Sumenep. Kabupaten Sumenep.

Haidar, Dimas Abdi dan Fajar, Surya Hutama. 2016. Persepsi Masyarakat Jawa Terhadap Tumbuhan Kelor Di Kecamatan Ambulu Jember. Prosiding Pengembangan Pendidikan KarakterBangssa Berbasis Kearifan Lokal dalam Era MEA. Univeritas Jember.

Katno dan Pramono, S. 2006. Tingkat Manfaat dan Keamanan Tumbuhan Obat dan Obat Tradisional. Jakarta: Rineka Cipta

Nasrudin, M. 2005. Inventarisasi Gulma Berpotensi Sebagai Obat di Lahan Tumpansari, desa Blaru, Kecamatan Pare, Kabupaten Kediri. Malang: UIN Malang

Prananingrum. 2007. Etnobotani Tumbuhan Obat Tradisional di Kabupaten Malang Bagian Timur. Malang: UIN Malang

Purwanto, Y. 1999. Peran dan Peluang Etnobotani Masa Kini di Indonesia Dalam Menunjang Upaya konservasi dan Pengembangan Keanekaragaman Hayati. Prosiding Seminar Hasil-hasil Penelitian Bidang Ilmu Hayat. Bogor: IPB

Robbins, S. P. 2003. Organizational Behaviour, Tenth Edition (Perilaku Organisasi edisi ke sepuluh), Alih Bahasa Drs. Benyamin Molan. Jakarta: PT. Mancanan Jaya Cemerlang.

Sekaran, Uma and Bougie, Roger. 2013. Research Methods for Business-A Skill-Building Approach : 6th Edition. John Wiley \& Sons Ltd.

Suryadarma. 2008. Etnobotani. Diktat Kuliah Jurusan Pendidikan Biologi MIPA: Universitas Negeri Yogyakarta

Hery Purnobasuki. 2013. Etnobotani Tumbuhan Obat Di Kabupaten Sumenep Jawa Timur. Jurnal Matematika dan Ilmu Pengetahuan Alam 16(01). Universitas Airlangga. 